DANIEL BOĆKOWSKI (Białystok)

\title{
POLSKA - ZSRR W XX WIEKU - PRZEGLĄD BIBLIOGRAFICZNY ZA LATA 2000-2005 (WYBÓR)
}

Po raz kolejny pozwalam sobie przedstawić wybór prac dotyczących stosunków polsko-radzieckich i polsko-rosyjskich w XX wieku, a także kwestii rosyjskich w ogóle, które ukazały się od 2000 do 2004 roku. Niniejszy zakres chronologiczny podyktowany jest docieraniem do mnie niektórych książek z dość dużym opóźnieniem, a nie chcę, by pozostały one niezauważone.

Dla ułatwienia zestawienie podzieliłem na poszczególne lata. Za punkt odniesienia przy dodawaniu książki do niniejszego spisu przyjąłem podaną przez wydawnictwo datę wydania, choć wiem, że nie zawsze jest to adekwatne do faktycznego czasu ukazania się danej pozycji. Wydawnictwo podaję dla ułatwienia nabycia ewentualnej pozycji - większość wydawnictw posiada już swoje księgarnie internetowe. Zdaję sobie sprawę, że prezentowany przegląd nie jest pełny, niemniej jednak opracowanie takie powinno pomóc wielu historykom w poszukiwaniach bibliograficznych.

\section{Rok 2000}

Hillel Levine, Kim pan jest panie Sugihara, Krajowa Agencja Wydawnicza, Warszawa 2000, ss. 309. Jest to historia japońskiego dyplomaty, Sugihary Chiune, który pracuje w Kownie w pierwszych miesiącach II wojny światowej jako wicekonsul. Wbrew stanowisku własnego rządu uratował od śmierci tysiące polskich Żydów, którym wystawiał wizy tranzytowe umożliwiające bezpieczny przejazd przez ZSRR pociągami „Inturistu” do portu w Szanghaju i dalej, np. do Holenderskich Indii Zachodnich, do których wizy wystawiał działający w Kownie holenderski konsul honorowy Jan Zwartendijk. Sugihara pomagał też aktywnie polskiemu wywiadowi działającemu 
w Kownie i Wilnie, zatrudnił też wielu Polaków u siebie, aby pomóc im materialnie. Sugihara jest postacią wyjątkową, gdyż za swoją pomoc nie chciał nigdy żadnych wyróżnień i podziękowań, a za swoją pomoc Żydom i Polakom zapłacił usunięciem ze służby dyplomatycznej. Zmarł w Japonii w 1986. Zanim to jednak nastąpiło setki uratowanych przez niego Żydów zdążyło go odnaleźć i podziękować. On sam zawsze powtarzał, że zrobił to co zrobił, gdyż taka była „wola Boża”. Książka oparta jest na wnikliwych badaniach archiwalnych autora, które przeprowadził w Polsce, na Litwie, w ZSRR i Japonii. Składa się z sześciu rozdziałów, w których omówione kolejno zostały losy Sugihary od czasów młodzieńczych aż do śmierci, ze szczególnym uwzględnieniem „okresu kowieńskiego".

\section{Rok 2001}

Giga Liparteliani, Prawda o Putinie. Polityczny kardiogram Rosji, Oficyna Wydawnicza Rytm, Warszawa 2001, ss. 110. 'Ta niewielka książeczka jest zbiorem uwag i przemyśleń autora na temat Putina i jego drogi na Kreml ułożonych $\mathrm{w}$ formie kalendarium, zaczynając od 10 marca $1985 \mathrm{r}$. (śmierci I sekretarza KC KPZR Konstantina Czernienki), poprzez cztery ostatnie lata poprzedzające wybór Putina na prezydenta Rosji. Datą zamykającą kalendarium jest 31 grudnia 1999 r. - moment podpisania i ogłoszenia przez Borysa Jelcyna decyzji o ustąpieniu ze stanowiska Prezydenta Federacji Rosyjskiej i przekazania tymczasowej władzy prezydenckiej w ręce ówczesnego premiera - Władimira Putina. Ostatnią część książki stanowią krótkie rozważania autora na temat stosunku Putina do komunistów, świata przestępczego, problemu czeczeńskiego oraz dwóch oligarchów: Gusińskiego i Borowina. Pracę zamyka bibliografia tematu i indeks osobowy.

\section{Rok 2003}

Piotr Gontarczyk, Polska Partia Robotnicza. Droga do wladzy 19411944, Fronda, Warszawa 2003, ss. 464. Głównym tematem niniejszej pracy są dzieje Polskiej Partii Robotniczej od pierwszych działań zmierzających do jej powołania, jakimi było spotkanie Georgija Dymitrowa ze Stalinem w sierpniu 1941 r., aż do chwili rozpoczęcia przez nią legalnej działalności na terenach zajętych tzw. Polski lubelskiej. Całość składa się z 15 rozdzia- 
lów oraz zakończenia, które zawiera szkice powojennych karier ważniejszych postaci wywodzących się z PPR i GL-AL. Pierwsze dwa rozdziały dotyczą zagadnień związanych $\mathrm{z}$ kształtem ruchu komunistycznego przed wybuchem wojny i jego działalnością w latach istnienia II RP. Zawierają też omówienie losów i postaw polskich komunistów działających na terenach wcielonych do ZSRR wschodnich województw Polski w latach 1939-1941. W rozdziale trzecim autor omawia sytuację strategiczną Związku Radzieckiego po wybuchu wojny z Niemcami oraz przyczyny, które skłoniły Kreml do podjęcia decyzji o powołaniu PPR i wysłaniu do kraju grupy inicjatywnej. W rozdziale czwartym omówione zostały procedury przerzutu do okupowanego kraju ludzi z grup inicjatywnych oraz struktury, jakie udało się wówczas utworzyć. Autor opisuje też wzajemne przenikanie się wpływów radzieckiego wywiadu wojskowego, NKWD i PPR oraz metody działania i sposoby konspiracji. W kolejnym rozdziale mowa jest o oficjalnej polityce prowadzonej w pierwszych miesiącach po powołaniu PPR oraz reakcji na ten nowy twór polityczny ze strony polskiego podziemia. Rozdział szósty poświęcony jest próbie analizy kłopotów organizacyjnych, jakie dotknęły komunistyczne struktury konspiracyjne na przełomie lat 1942/1943, aresztowaniom, które nieomal doprowadziły do rozbicia organizacji oraz zabójstwom dwóch pierwszych sekretarzy: Marcelego Nowotki i Bolesława Mołojca. Rozdziały siódmy, dziesiąty i trzynasty, dotyczą powstania, rozwoju i działalności komunistycznej partyzantki GL-AL. P. Gontarczyk omawia szczegółowo dzieje partyzantki komunistycznej w 1942 r., 1943 r. oraz w latach 1944-45 (zasięg działania oddziałów, dane dotyczące ich faktycznej liczebności, zadań, jakie miały wykonać oraz metod działania). Uzupełnieniem tych części jest rozdział jedenasty poświęcony w całości konfliktom zbrojnym pomiędzy partyzantką związaną z PPR a oddziałami wiernymi rządowi polskiemu $\mathrm{w}$ Londynie. W rozdziale ósmym autor zapoznaje nas z rozmowami prowadzonymi wiosną 1943 r. pomiędzy PPR a przedstawicielami Delegatury Rządu na Kraj. Przybliża cele, jakie stawiały sobie obie uczestniczące $w$ rozmowach strony oraz zastanawia się nad możliwościami porozumienia, zwłaszcza w obliczu prowadzonej przez PPR zorganizowanej akcji niszczenia podziemia niepodległościowego przy wykorzystaniu donosów wysyłanych do Gestapo. Rozdział dziewiąty poświęcony jest narastającym kontrowersjom pomiędzy PPR w kraju a Moskwą, zwłaszcza w sprawie tzw. deklaracji marcowej a także postawie PPR wobec ujawnionej przez Niemcy zbrodni katyńskiej, która w sposób zasadniczy zaważyła na całokształcie stosunków pomiędzy podziemiem londyńskim a komunistami. W rozdziale dwunastym przedstawiony został zwrot poli- 
tyczny PPR dokonany jesienią 1943 r. - deklaracja listopadowa, powstania KRN, próba rozszerzenia wpływów PPR na inne organizacje konspiracyjne. W rozdziale czternastym ukazane zostały ostatnie miesiące działania PPR w konspiracji. Rozdział piętnasty omawia okoliczności, które spowodowały, że mimo głębokiej nieufności Moskwa postawiła ostatecznie na PPR porzucając ideę opanowania Polski siłami komunistów znajdujących się w ZSRR. Pracę kończy podstawowa bibliografia tematu, oraz indeks osób.

Aleksander Wasilewski, Granica lorda Curzona, polska granica wschodnia od Wersalu do Schengen (traktaty, umowy, przejścia graniczne, podróżni, wizy), Wydawnictwo Adam Marszałek, Toruń 2003, ss. 210. Książka ta stanowi prawno-historyczny przegląd zmian, jakim podlegała polska granica wschodnia od momentu odzyskania przez Polskę niepodległości w 1918 r. aż do lat dziewięćdziesiątych, kiedy Polska nie zmieniając: swego położenia geograficznego zmieniła swoich wschodnich sąsiadów. Praca składa się z czterech rozdziałów. Rozdział pierwszy dotyczy lat 1918-1939. Autor kolejno omawia w nim wojnę polsko-radziecką o środkowo-wschodni odcinek granicy, jej przebieg na odcinku północno-wschodnim, w tym spór o Wilno i Kłajpedę z Litwą oraz sytuację dyplomatyczną - działalność konsularną, reżim wizowy, płytki wywiad. Rozdział kończy aneks, w którym znalazły się najważniejsze dokumenty dyplomatyczne dotyczące granicy wschodniej w omawianym okresie. W rozdziale drugim mowa jest o problemie polskiej granicy wschodniej w latach II wojny światowej. Kolejno A. Wasilewski omawia układy radziecko-niemieckie, sprawę granicy wschodniej w polityce rządu RP na emigracji, układ Sikorski-Majski oraz kwestię granicy wschodniej na konferencjach w Teheranie, Jałcie i Poczdamie. Także ten rozdział kończą aneksy zawierające najważniejsze dokumenty $\mathrm{z}$ tego okresu. W rozdziale trzecim omówiona została polska granica wschodnia w latach 1945-1991, zwłaszcza zaś sytuacja, jaka wytworzyła się z chwilą upadku ZSRR, kiedy zaistniała pilna potrzeba ponownego unormowania kwestii granicznych z powstałymi po rozpadzie ZSRR sąsiadami: Białorusią, Ukrainą, Litwą i Rosją. Także tę część kończy aneks. W ostatnim rozdziale A. Wasilewski pisze o polskiej drodze do Schengen i dostosowywaniu polityki wizowej paístwa do wymogów Unii Europejskiej. Na końcu pracy umieszczony został jeszcze jeden aneks, w którym znalazły się podpisane przez Polskę umowy z Rosją, Ukrainą i Białorusią o zasadach wzajemnych wyjazdów obywateli Rzeczypospolitej Polskiej i obywateli tychże krajów. Praca zawiera bibliografię oraz indeks osób. 


\section{Rok 2004}

Piotr Eberhardt, Polska i jej granice. $Z$ historii polskiej geografii politycznej, Wydawnictwo UMSC, Lublin 2004, ss. 302. Celem niniejszej pracy jest zaprezentowanie indywidualnych poglądów uczonych oraz działaczy politycznych na temat im współczesnej lub przyszłej Polski posługując się argumentacją geograficzną, czyli nawiązując zasadniczo do terytorium, na jakim znajdowała się lub powinna się «naleźć Polska. P. Eberhardt omawia w swej książce prace powstałe w ciągu ostatniego tysiąclecia, począwszy od Galla Anonima i Długosza, a skończywszy na historykach i geografach tworzących współcześnie. Ich cechą wspólną jest poruszanie kwestii historycznego i geograficznego „miejsca” Polski w Europie. Książka składa się z dziewięciu części, w których P. Eberhardt omówił kolejno: prace wielkich kronikarzy i dziejopisarzy na temat położenia Polski i jej granic, początki polskiej kartografii, myśl geograficzną polskiego oświecenia i początków XIX wieku, wizje Polski i jej granic w koncepcjach geograficznych przelomu XIX i XX wieku, wizje graniczne państwa polskiego w pracach badaczy okresu I wojny światowej, a także polską myśl geograficzną o granicach państwa $w$ okresie międzywojennym. Dla nas najważniejsze są trzy ostatnie rozdziały książki, w których omówione kolejno zostały koncepcje granic państwa polskiego w opracowaniu geografów i działaczy politycznych w latach drugiej wojny światowej (koncepcje ugrupowań emigracyjnych oraz promoskiewskich), polska myśl geograficzna o położeniu paístwa polskiego po drugiej wojnie światowej oraz współczesna myśl geograficzna o położeniu i granicach Polski. Pracę kończy obszerna bibliografia tematu oraz spis rycin, których zamieszczono w książce 40 - od tych z czasów najdawniejszych, po współczesne. Minusem pracy jest brak indeksu osobowego.

Europa Środkowa $i$ Wschodnia $w$ XX wieku. Studia ofiarowane Wieslawowi Balcerakowi w siedemdziesiqtq rocznicę urodzin, pod redakcją naukową Andrzeja Koryna i Piotra Łossowskiego, Wydawnictwo IH PAN, Warszawa - Łowicz 2004, ss. 621. Praca składa się z pięciu części. W pierwszej znalazła się bibliografia prac W. Balceraka za lata 1958-2003 oraz cztery artykuły poświęcone sylwetce Profesora. W dalszej części książki znalazły się studia ofiarowane Profesorowi przez przyjaciól, podzielone tematycznie na te dotyczące Polski, Europy Środkowo-Wschodniej i Rosji. Do najciekawszych artykułów zaliczyć można niewątpliwie tekst Janusza Wojtasika o wschodnich granicach odrodzonej Rzeczypospolitej w polskiej myśli politycznej do 1918 roku, Joanny Gierowskiej-Kałłałur o organizacji służby bezpie- 
czeństwa na ziemiach podległych Zarządowi Cywilnemu Ziem Wschodnich w okresie od lutego 1919 do września 1920 r., Andrzeja Nowaka o historiografii wojny polsko-bolszewickiej ostatnich lat, w którym autor zastanawia się na ile współczesne publikacje stanowią przełom a na ile są początkiem nowych problemów i nieporozumień we wzajemnych polsko-rosyjskich relacjach, Daniela Boćkowskiego o polskich Żydach na Białostocczyźnie w okresie okupacji radzieckiej 1939-1941 oraz ugruntowanym wówczas stereotypie „żydokomuny", budowanym na micie powszechnej i masowej kolaboracji ludności żydowskiej z radzieckim okupantem, Jana Sobczaka o dziejach polityki wewnętrznej Rosji w pierwszej dekadzie panowania cara Mikołaja II oraz Aleksandry J. Leinwand o Włodzimierzu Majakowskim oraz Damianie Biednym - mistrzach propagandy w okresie wojny polsko-bolszewickiej 1920 r. Bardzo interesujący jest tei artykuł Hanny Marczewskiej-Zagdańskiej o polityce amerykańskiej na Bałkanach w latach 1940-1941 w obliczu rosnącej aktywności w tym rejonie Trzeciej Rzeszy oraz ZSRR.

Michał Gnatowski, Polacy - Sowieci - Żydzi w regionie lomżyńskim $w$ latach 1939-1941, Tom II: Dokumenty radzieckie, Łomżyńskie Towarzystwo Naukowe im. Wagów, Łomża 2004, ss. 300. Praca wydana została w serii „Polacy i Żydzi w regionie łomżyńskim”. Tom pierwszy ukazał się dopiero w 2005 r. W przygotowaniu są też tomy III i IV. Znajdą się w nich dokumenty polskie i żydowskie. W omawianym tomie M. Gnatowski umieścił 54 przetłumaczone na język polski dokumenty radzieckie pochodzące z Narodowego Archiwum Republiki Białorusi w Mińsku oraz Państwowego Archiwum Organizacji Społecznych Obwodu Grodzieńskiego w Grodnie. Jedynie dwa dokumenty: Uchwała RKL ZSRR z 2 marca 1940 r. w sprawie ochrony granicy państwowej zachodnich obwodów USRR i BSRR oraz Dyrektywa LK NKWD ZSRR z 10 czerwca 1940 r. w sprawie wysiedlenia „bieżeńców” z USRR i BSRR pochodzą z archiwów moskiewskich. Większość dokumentów nie była dotąd nigdzie publikowana. Ułożone są one w porządku chronologicznym. 5 dokumentów dotyczy 1939 r., 43 - 1940 r., 6 - 1941 r. Pierwszy dokument pochodzi z 12 października 1939 r. i jest to wyciąg z meldunku operacyjnego ludowego komisarza spraw wewnętrznych BSRR charakteryzujący działającą w Łomży żydowską partię Poalej Syjon. Ostatni dokument pochodzi z 20 maja 1941 r. Jest nim pismo okólne Komitetu Obwodowego KP(b)B w Białymstoku do komitetów miejskich i rejonowych $\mathrm{w}$ sprawie przeciwdziałania zgromadzeniom młodzieży przed kościołami. Zaniepokojenie białostockiego Obkomu wzbudziły nabożeństwa majowe, na których „odbywa się spowiedź podrostków i młodzieży”. Tra- 
dycyjne w tym czasie procesje wokół kościołów władze uznały za zorganizowane przez księży demonstracje, w które kler katolicki pragnie wciągnąć młodzież. Aby przeciwdziałać tym działaniom należało - zdaniem lokalnych władz partyjnych - „nasilić propagandę antyreligijną, zwłaszcza wśród młodzieży i nauczycieli". Już z tej krótkiej charakterystyki widać, że tom ten ma w zamyśle jego twórcy ukazać wszystkie aspekty radzieckiej polityki narodowościowej, która równie baczną uwagę zwracała na Polaków, jak i na Żydów. W zamieszczonych tu dokumentach jak na dłoni widać politykę „dziel i rządź”, która doprowadziła do głębokiego zantagonizowania obu lokalnych społeczności, co z kolei zaowocowało latem 1941 r. zbrodniami popełnionymi m.in. w Jedwabnem. Widać też, szczególnie w dokumentach z lata 1940 r., jak zmienia się stanowisko Kremla, a za nim Mińska w kwestii roli, jaką mają do odegrania Polacy w sytuacji, gdy nieoczekiwana klęska Francji oraz pogorszenie wzajemnych stosunków niemiecko-radzieckich wieszczy nieuchronne zbliżanie się wojny. Wiele dokumentów przedstawia ogólne aspekty radzieckiej polityki na omawianyın terenie, część pokazuje zastaną tam sytuację społeczno-polityczną, z którą nawet władza radziecka nie potrafi sobie poradzić. Doskonałym tego przykładem jest meldunek naczelnika łomżyńskiego NKWD o chuligańskich wybrykach przeradzających się $\mathrm{w}$ bijatyki pomiędzy polską i żydowską młłodzieżą szkolną. W dokumentach widać wyraźnie narastającą wrogość, chęć odwetu, przenoszenie na całą żydowską społeczność oskarżeń o antypolską i antynarodową postawę. Jest to pośredni wynik radzieckiej polityki faworyzowania mniejszości narodowych kosztem Polaków. Jego efektem jest pogłębiająca się wrogość pomiędzy społecznością polską i żydowską. Dlatego nikogo nie powinny dziwić cytowane w ww. dokumencie okrzyki „Już niedługo będzie tu Armia Czerwona. Dobrze wam Żydom teraz, ale poczekajcie, będzie wam źle”, czy też „Poczekajcie, już niedługo będą tu bolszewicy, wtedy my z wami Żydami policzymy się". Zbiór zamykają dwa indeksy -- geograficzny i nazwisk.

Richard Pipes, Żylem, wspomnienia niezależnego, Wydawnictwo MAGNUM, Warszawa 2004, ss. 266. Jest to napisana bardzo dobrym, żywym językiem autobiografia jednego z najwybitniejszych amerykaískich historyków polskiego pochodzenia, sowietologa, autora monumentalnego tryptyku poświęconego historii Rosji, na który składają się: Rosja carów, Rewolucja rosyjska oraz Rosja bolszewików, współtwórcy amerykańskiej polityki wobec ZSRR w najaktywniejszym okresie zimnej wojny za czasów prezydentury Ronalda Reagana. Żylem jest pasjonującą lekturą pokazującą nam nie tylko samego Pipesa i jego drogę od Cieszyna, gdzie się urodził, przez Harvard 
i Waszyngton, gdzie przez lata pracowal i tworzył, aż do odejścia na emeryturę. Pokazuje także pewien okres w historii USA, ewoluc.ję poglądów amerykańskich na ZSRR oraz rozwijanie się i dojrzewania amerykańskiej szkoły sowietologicznej, której niezaprzeczalnym autorytetem był twórca niniejszej biografii. Książka R. Pipesa składa się trzech części. W pierwszej autor opisuje dzieje swoje i swojej rodziny w okresie międzywojennym w Polsce, ucieczkę przed zbliżającą się wojną do Włoch, wyjazd w 1940 r. do USA, studia, służbę w armii po wybuchu wojny amerykańsko-japońskiej, gdzie skierowano go w ramach szkolenia na naukę języka rosyjskiego i gdzie rozpoczęła się jego „przygoda” z Rosją. W części drugiej Pipes opisuje swoją pracę na Harvardzie, pierwsze fascynacje Rosją i jej historią, ludzi, którzy wpłynęli na jego zainteresowania badawcze, powstawanie Rosji carów, która ugruntowała jego pozycję naukową oraz potwierdziła dla wielu kręgów rosofili, że reputacja zdecydowanego wroga komunizmu oraz nieprzejednanego zwolennika twardej polityki wobec Związku Radzieckiego jest jak najbardziej prawdziwa. W części trzeciej autor opisuje swoją przygodę $\mathrm{z}$ wielką polityką, która zaczęła się od powołania go na kierownika tajnego zespołu ekspertów odpowiedzialnego za ocenę radzieckiej strategii nuklearnej oraz sposobów odpowiedzi na to zagrożenie ze strony USA. Dalej możemy przeczytać o jego pracy w Radzie Bezpieczeństwa Narodowego i Departamencie Stanu. Pipes pisze też o swoje współpracy w prezydentem USA Ronaldem Reaganem w czasie kryzysu 1981 r. w Polsce, i jest to jeden z najciekawszych fragmentów jego wspomnień odsłaniający kulisy krystalizowania się amerykańskiej polityki wobec gen. Jaruzelskiego i jego ekipy, zakończone wprowadzeniem sankcji ekonomicznych i politycznych wobec Polski a następnie ZSRR oraz powstawania Dyrektywy Decyzyjnej w sprawie Bezpieczeństwa Narodowego, która na wiele lat wyznaczyła ostry i bezkompromisowy kurs USA wobec ZSRR. W części czwartej czytamy o powrocie autora do pracy w Harvardzie, o okolicznościach powstawania Rewolucji rosyjskiej, odwilży w Związku Radzieckim i rozdarciu amerykańskich sowietologów, którzy bardziej wierzyli w trwałość Związku Radzieckiego niż jego przywódcy i którzy poczuli się ,zdradzeni” faktem jego nagłego upadku. Całość pracy kończy indeks nazwisk.

Tomasz Strzembosz, Antysowiecka partyzantka $i$ konspiracja nad Biebrzq X 1939 - VI 1941, Wydawnictwo Neriton, Warszawa 2004, ss. 236. Książka obszernie omawia niezbadane dotychczas zagadnienia związane z działalnością polskiej partyzantki antysowieckiej oraz konspiracji zorganizowanej nad Biebrzą od jesieni 1939 r. do wkroczenia na te tereny armii 
niemieckiej w czerwcu $1941 \mathrm{r}$. Jest to ostatnia praca profesora Tomasza Strzembosza, stanowiąca podsumowanie ponad 20 lat wędrówek po wsiach po obu stronach Biebrzy w celu zbierania relacji od świadków i uczestników tamtych wydarzeń, uzupełnionych wynikami kwerend źródłowych $\mathrm{w}$ archiwach polskich i białoruskich. Praca składa się z trzech części. W części pierwszej autor charakteryzuje region nadbiebrzański w czasie wojny i okupacji radzieckiej w latach 1939-1941, kolejno omawiając kampanię wrześniową, zajęcie tych terenów najpierw przez wojska niemieckie a następnie radzieckie, tworzenie się i zasady działania radzieckiego systemu okupacyjnego na „Zachodniej Białorusi” oraz sytuację Podlasia w nowych strukturach polityczno-administracyjnych Białoruskiej SRR. W części drugiej omówiona została konspiracja i partyzantka na tych ziemiach do lata 1941 r. Autor opisuje powstanie sieci konspiracyjnej $\mathrm{w}$ regionie nadbiebrzańskim, dzieląc ją na dwie fazy: fazę organizacyjną, trwającą od jesieni 1939 r. do wiosny 1940 r. oraz pełnego rozwoju od marca do czerwca 1940 r. Szczególny nacisk kładzie na powstanie partyzantki na uroczysku Kobielno, gdzie wybudowana zostaje duża baza partyzancka, będąca centrum koordynacyjnym całego ruchu oporu w tym regionie. Część trzecia poświęcona jest w całości rozbiciu przez wojsko i NKWD bazy na uroczysku Kobielno i konsekwencji tych wydarzeń dla lokalnego ruchu oporu, który mimo zadanych strat odrodził się i kontynuował walkę aż do maja 1941 r. Pracę kończy bibliografia tematu, indeks nazw i pseudonimów oraz indeks nazw geograficznych.

Swiat niepożegnany. Żydzi na dawnych ziemiach wschodnich Rzeczypospolitej $w X V I I I-X X$ wieku, red. Krzysztof Jasiewicz, Oficyna Wydawnicza RYTM, Warszawa -- Londyn 2004, ss. 1120. Niniejsza książka jest drugim monumentalnym dziełem zbiorowym poświęconym sprawom wschodnich ziem Rzeczypospolitej, które ukazało się dzięki benedyktyńskiej pracy znakomitego historyka Krzysztofa Jasiewicza. Na siedem kolejnych części tej książki składają się artykuły 97 autorów z 12 krajów reprezentujących 71 placówek naukowo-badawczych i akademickich. Już sam początek tej książki jest niezwykły, gdyż umieszczono tam Kadisz, modlitwę za zmarłych, co oznacza, że zgodnie $\mathrm{z}$ religią żydowską książki tej nie wolno wyrzucić na śmietnik ani spalić, a jedynie pogrzebać w ziemi. W części pierwszej Między świtem a zmierzchem Narodu Wybranego znalazły się m.in. teksty dotyczące początków osadnictwa żydowskiego na ziemiach litewsko-białoruskich (S. Alexandrowicz), liczebności i rozmieszczenia ludności żydowskiej na kresach I i II Rzeczypospolitej (P. Eberhardt), emigracji Żydów z Ukrainy Zachodniej do Stanów Zjednoczonych w latach 1919-1939 (S. Kacza- 
raba), losów żydowskich uchodźców przebywających na Kresach Północno-Wschodnich w czasie II wojny światowej (D. Boćkowski), losów Żydów na Zachodniej Białorusi w okresie Holocaustu (J. Rozenbłat), dylematów repatriacyjnych Żydów polskich znajdujących się w ZSRR (A. Głowacki) oraz losów Żydów w Litewskiej SRR od 1944 do 1990 r. (I. Mikłaszewicz). W części drugiej Wśród struktur politycznych na szczególną uwagę zasługują opracowania H. Astera i P. J. Potichnego o problemach diaspory żydowskiej, O. Pawłyszyna o Żydach wschodniogalicy jskich w okresie Zachodnioukraińskiej Republiki Ludowej, A. Suchcitza o postawie Żydów w obliczu upadku Rzeczypospolitej na podstawie relacji polskich z Kresów Wschodnich oraz esej S. Janowicza o obrazie Żydów w oczach zwykłych Białorusinów. Część trzecia Stosunki międzyetniczne zawiera bardzo ciekawe opracowanie autorstwa M. Dajnowicz o stosunkach polsko-żydowskich w Łomżyńskim na przełomie XIX i XX wieku, J. Gierowskiej-Kałłałur o Żydach i Polakach na Wileńszczyźnie i Grodzieńszczyźnie w latach 1919-1920 oraz J. Wołkonowskiego o współistnieniu polsko-żydowskim w Wilnie w okresie międzywojennym. W części IV Wobec armii, sil politycznych i konspiracji znalazły się m.in. teksty poświęcone stosunkowi UPA do kwestii żydowskiej (G. Motyka), konspiracji i walce Żydów na Kresach Południowo-Wschodnich (J. Węgierski), partyzantce żydowskiej na Kresach Północno-Wschodnich i jej stosunku do AK (M. Iwanow) oraz stosunku polskiego ruchu oporu do Żydów (B. Chiari). Na część V Zanim zrozumiano slowo Shoah składają się teksty W. Wierzbieńca o zajściach antyżydowskich w Przemyślu pod koniec 1918 r., A. Czerniakiewicza o ekscesach antyżydowskich wojsk polskich na Kresach Północno-Wschodnich w 1919 r., O. Sobolewskiej o pogromach ludności żydowskiej w Grodnie w okresie międzywojennym oraz W. Śleszyńskiego o zajściach antyżydowskich w Brześciu w 1937 r. W części VI Teoria mordów sqsiedzkich znalazły się teksty poświęcone m.in. zbrodni w Jedwabnem (J. Michlic, A. Ezergalis, A. Polonsky), zagładzie Żydów na Litwie (D. Lenin), ratowaniu Żydów przez chrześcijan na terytorium Białorusi w latach 1941-1944 (L. Michajlik) oraz stosunkom polsko-żydowskim na przykładzie jednej wsi w regionie białostockim (A. Żbikowski). Część VII pracy stanowi obszerny zbiór relacji i opisów zbrodni dokonywanych na ludności żydowskiej we wschodnich województwach II RP, Bukowinie oraz państwach bałtyckich. Pracę zamyka obszerny rozdział VIII Jak pisać o trudnej historii. Nad tym niełatwym pytaniem zastanawia się 37 autorów, w tym J. T. Gross, E. Wnuk-Lipiński, J. Holzer, J. Jedliński, J. Tomaszewski, M. J. Chodakiewicz, Z. Gluza, D. Nałęcz, Cz. Grzelak, A. Mencwel, S. Nowikow, S. Chazbijewicz i M. Kula. Pracę kończą noty biograficzne autorów tekstów, relacji 
i wspomnień, streszczenia artykułów w języku angielskim oraz indeks nazwisk.

\section{Rok 2005}

Anne Applebaum, Gulag, Świat Książki, Warszawa 2005, ss. 624. Jest to jedna $\mathrm{z}$ najlepszych książek napisanych na temat Gułagu w ostatnich latach. Anne Applebaum, prywatnie żona Radka Sikorskiego, dziennikarka „Washington Post” przez wiele lat zbierała materiały (pamiętniki, relacje, dokumenty archiwalne) rozrzucone po archiwach rosyjskich (od Moskwy po Syktywkar, Workuję, Wyspy Sołowieckie, Perm i Archangielsk), amerykańskich i polskich, dzięki czemu powstało dzieło dorównujące pracy Sołżenicyna. Autorka w sposób niezwykle drobiazgowy, zgodnie z najnowszymi badaniami, kreśli obraz Gułagu - od momentu jego powstania, przez apogeum lat czterdziestych aż po ich zmierz w latach osiemdziesiątych. Zmierz nie oznacza jednak końca tej formy represji. We współczesnej Rosji kolonie pracy poprawczej do dziś mają się dobrze i stale trafiają do nich więźniowie, coraz częściej także z przyczyn politycznych, choć wyroki na nich wydane, zgodnie $\mathrm{z}$ wieloletnią radziecką tradycją, dotyczą zupełnie innych spraw. Anne Applebaum wnikliwie opisuje system łagrowy rozrzucony po całym obszarze Związku Radzieckiego, zauważając, że kolonie karne znajdowały się zarówno w odległej Workujcie, jak i centrum Moskwy czy też przedmieściach Leningradu. Pokazuje jak system ten ewaluował stając się jednym z podstawowych filarów radzieckiej gospodarki, która wielkie budowle socjalizmu oparła na niewolniczej sile roboczej milionów więźniów. W swojej pracy autorka obszernie korzysta z polskiej literatury lagrowej oraz relacji zgromadzonych m.in. w Ośrodku KARTA w Warszawie. Książka składa się z trzech zasadniczych części. W części pierwszej omawia ona początki Gułagu prowadząc nas najbardziej charakterystycznymi etapami jego rozwoju - Wyspy Sołowieckie, które były kolebką obozów pracy przymusowej, Kanał Białomorski, który dał literaturze łagrowej pojęcie „zeka" oraz Wielki Terror, dzięki któremu zaludniły się obozy setkami tysięcy nowych więźniów. W części drugiej autorka szczegółowo opisuje życie i pracę w obozach, kolejno omawiając aresztowanie, więzienie, transport i selekcję, życie codzienne, pracę, system kar i nagród mający zmusić więźnia do morderczej pracy ponad siły, strategię przetrwania w warunkach, które $\mathrm{z}$ góry obliczone były na uśmiercenie lagiernika po jego wykorzystaniu fizycznym, udane i nieudane ucieczki $\mathrm{z}$ obozów oraz wybuchające zwłaszcza w latach 
pięćdziesiątych, krwawo tłumione bunty więźniów politycznych. Opisuje też strażników, samych więźniów, kobiety i dzieci w obozach, „dochadiagów” określanych tu jako umrzyki. Stworzony przez nią obraz systemu jest moim zdaniem w wielu miejscach pełniejszy niż ten stworzony przez Sołżenicyna, a na pewno równie wstrząsający. W części trzeciej ponownie wracamy do historii samego Gułagu. Anne Applebaum kolejno ukazuje nam system obozowy w czasie wojny, pierwsze amnestie, apogeum Gułagu jako jednego z najwydajniejszych kompleksów przemysłowych aktywnie uczestniczącego w odbudowie i uprzemysłowieniu powojennego ZSRR, okres po śmierci Stalina - pełen oczekiwań nadziei na odwilż, który zakończył się buntami zeków, nazywanym przez autorkę rewolucją. Na koniec czytelnik może zapoznać się z dziejami Gułagu, które z przyczyn oczywistych nigdy nie znalazły się w monumentalnym Archipelagu - epoce dysydentów oraz latach osiemdziesiątych. Pracę kończy aneks, w którym autorka stara się ocenić ile osób przewinęło się przez system obozowy (otrzymuje przejmującą liczbę 28,7 miliona osób), bibliografia tematu (szczególnie cenna ze względu na wymienią tam niezwykle skrupulatnie literaturę wspomnieniową, która ukazała się na zachodzie), słowniczek terminologii łagrowej oraz indeks osobowy.

Ludwik Bazylow, Paweł Piotr Wieczorkiewicz, Historia Rosji, Ossolineum, Wrocław 2005, ss. 632. Niniejsza praca jest kolejnym, czwartym już wydaniem fundamentalnego dzieła Ludwika Bazylowa, poprawionym i uzupełnionym przez Pawła Piotra Wieczorkiewicza, który jest jednocześnie autorem rozdziałów, w których opisana została historia ZSRR i Rosji lat 1917-1991. Tym samym otrzymaliśmy do ręki najlepsze jak dotąd opracowanie dziejów Rosji od czasów najdawniejszych po czasy nam współczesne, które $\mathrm{w}$ tej formie i w taki sposób uwzględniające dzieje ZSRR nigdy wcześniej nie mogłoby się ukazać. Całość składa się z 22 rozdziałów. Paweł Wieczorkiewicz uzupełnił i uaktualnił ostatnie rozdziały autorstwa L. Bazylowa, w których była mowa o rozwoju ruchu robotniczego, roli bolszewików i Lenina, oraz genezie rewolucji 1917 r. Uzupełnił także fragmenty tekstu dotyczące najbardziej drażliwych wydarzeń ze wspólnej historii Polski i Rosji, które w czasach cenzury i „przyjaźni polsko-radzieckiej” ze zrozumiałych względów w formie takiej jak dziś nie mogły się ukazać. Spod jego pióra wyszły też rozdziały omawiające kolejno przewrót październikowy, wojnę domową, państwo Lenina, drogę ZSRR ku państwu totalitarnemu, wielki terror, wojnę ojczyźnianą, powojenne imperium Stalina, epokę Chruszczowa, lata zastoju Breżniewa oraz gorbaczowską pierestrojkę zakończoną rozpadem ZSRR. Pracę kończą wskazówki bibliograficzne, wybrana literatura 
przedmiotu opublikowana w Polsce po 1990 r., rozbudowany indeks nazwisk, indeks nazw geograficznych i etnicznych oraz spis map.

Daniel Boćkowski, Na zawsze razem. Bialostocczyzna i Lomżyńskie w polityce radzieckiej w czasie II wojny światowej (IX 1939 - VIII 1944), Wydawnictwo Neriton, Warszawa 2005, ss. 333. Jest to podsumowanie kilku ostatnich lat badań poświęconych radzieckiej polityce wobec północno-wschodnich ziem II RP włączonych do ZSRR. Polityka ta przestawiona została na przykładzie obwodu białostockiego, w którego skład weszła Białostocczyzna i Łomżyńskie. W książce znaleźć można próbę odpowiedzi na dwa zasadnicze pytania: w jakim stopniu władzy radzieckiej udało się zrealizować swoje plany z jesieni 1939 r. oraz jaką rolę odgrywała Białostocczyzna w planach Kremla oraz Mińska do momentu przekazania jej stronie polskiej latem 1944 r. Autor pokazuje też, że polityki radzieckiej wobec „Zachodniej Białorusi" nie zmieniło ani zagarnięcie tych ziem przez wojska niemieckie, ani nawiązanie polsko-radzieckich stosunków dyplomatycznych. Kreml nawet przez chwilę nie przestał myśleć o tych ziemiach jako o nierozerwalnej na wieki części składowej radzieckiego imperium. Praca ma układ chronologiczno-tematyczny i składa się dwóch części. W części pierwszej omówione zostało kształtowanie się władzy radzieckiej od września 1939 r. do stycznia 1944 r., polityka radziecka na terenie obwodu białostockiego w latach 1940-1941, ze szczególnyın uwzględnieniem spraw kadrowych, narodowościowych, gospodarczych oraz prawnych. W części drugiej omówiona została polityka radziecka, a zwłaszcza polityka władz białoruskich działających wówczas w Moskwie, wobec wschodnich ziem II RP znajdujących się pod okupacją niemiecką. W kolejnych rozdziałach autor opisał krystalizowanie się radzieckich planów powrotu do obwodu, znaczenie partyzantki radzieckiej w opanowywaniu, a przynajinniej próbie opanowania „zachodnich obwodów BSRR", a także plany Kremla co do przyszłości obwodu białostockiego, który od spotkania Wielkiej Trójki w Teheranie stał się ważnym elementem przetargowym. Pod koniec tej części omówiona została skomplikowana sytuacja Białostocczyzny w przeddzień „wyzwolenia” oraz w pierwszych tygodniach i miesiącach po zainstalowaniu się na tych terenach cywilnych władz białoruskich i polskich. Pracę kończą: obszerna bibliografia tematu, indeks osób oraz indeks geograficzny a także aneks z faksymiliami kilku dokumentów $\mathrm{z}$ tego okresu.

Bożena Diemjaniuk, Bieżeńcy, Oficyna Wydawnicza Stopka, Łomża 2005 , ss. 97. Jest to jedna $\mathrm{z}$ pierwszych prób przybliżenia zwykłym czy- 
telnikom problemu „bieżeństwa”, szczególnie tego z okresu pierwszej wojny światowej. Bieżeństwa - czyli przymusowej ewakuacji tysięcy mieszkańców wsi białoruskich w głąb Rosji carskiej przed nacierającymi wojskami niemieckimi. Praca ta składa się $\mathrm{z}$ trzech całkowicie niezależnych od siebie części, przedstawiających w różnej formie to wszystko, czego doświadczyli wówczas ludzie. Pozwala też lepiej zrozumieć stosunek ludności białoruskiej do władzy radzieckiej po 17 września 1939 r. W części I omówione zostały losy bieżeńców na przykładzie jednej rodziny, w części drugiej losy bieżeńców opisywane są z perspektywy współczesnej młodej białoruskiej dziewczyny, która poszukuje wśród starych ludzi świadków tamtych dni. Część trzecia ma formę modlitwy. Na końcu pracy znajduje się kilkustronicowe omówienie tego problemu w oparciu o najnowsze badania historyczne, także wnioski samej autorki.

Michał Gnatowski, Polacy - Sowieci - Żydzi w regionie lomżyńskim w latach 1939-1941, Tom I: Studia, Łomżyńskie Towarzystwo Naukowe im. Wagów, Łomża 2005, ss. 248. Jest to pierwszy tom serii „Polacy i Żydzi w regionie łomżyńskim". Z przyczyn technicznych ukazał się jednak jako drugi. Tom drugi, zawierający dokumenty radzieckie ukazał się w 2004 r. W przygotowaniu są tomy III i IV, w których znajdą się dokumenty i relacje polskie oraz żydowskie do tego tematu. Omawiany tom jest zbiorem studiów poświęconych skomplikowanym relacjom polsko-żydowskim $\mathrm{w}$ regionie łomżyńskim w okresie okupacji radzieckiej 1939-1941. Autor omawia tu dzieje dwóch społeczności, żyjących do wojny w zgodzie i spokoju, mimo znaczących nawet sporów nieporozumień oraz konfliktów interesów, zwłaszcza ekonomicznych. Wejście na te ziemie Armii Czerwonej z hasłami wyzwalania uciśnionej mniejszości białoruskiej, której na tym terenie nie było spowodowało, że jedyną „uciskaną mniejszością", którą przyszło wyzwolić stali się Żydzi. Uznanie Żydów za „ofiary”, zaś Polaków za „sprawców ich cierpień" wraz z zepchnięciem Polaków „za karę” w dół drabiny społecznej w sposób nieodwracalny podzieliło miejscową społeczność i zaowocowało latem 1941 r. licznymi pogromami żydowskimi, których symbolem stało się Jedwabne. $O$ tych właśnie trudnych czasach mowa jest $\mathrm{w}$ prezentowanym tu tomie. Praca składa się z trzech rozdziałów i aneksu. W rozdziałach M. Gnatowski omawia kolejno sytuację regionu łomżyískiego pod okupacją radziecką 1939-1941, politykę narodowościową władz radzieckich w regionie, ze szczególnym uwzględnieniem sytuacji ludności polskiej i żydowskiej oraz założeń radzieckiej polityki narodowościowej i problemów z praktyczną realizacją tych założeń $\mathrm{w}$ terenie, a także stosunki polsko-żydowskie $\mathrm{w}$ re- 
gionie łomżyńskim w latach 1939-1941, dzieląc je na kilka etapów: pierwszy - to stosunki wzajemne w okresie „wyzwalania” tych ziem oraz działalności zarządów tymczasowych (wrzesień - grudzień 1939 r.), drugi - stosunki wzajemne po włączeniu regionu w skład Białoruskiej SRR (styczeń 1940 czerwiec 1941 r.). Rozważania o wzajemnych relacjach polsko-żydowskich kończy autor omówienieın stereotypu „żydokomuny” oraz „polskiego antysemityzınu" w regionie w latach 1939-1941, wskazując na znacznie wcześniejsze osadzenie ich $\mathrm{w}$ zbiorowej świadomości mieszkańców regionu, $\mathrm{z}$ tą jednak różnicą, że „Żyd-komunista” nie był aż tak jednoznacznie kojarzony z miejscową społecznością żydowską. Dopiero polityka radziecka sprawiła, że Żydzi, którzy nie zareagowali tak jak tego oczekiwali od nich ich „polscy sąsiedzi" na fakt wkroczenia Sowietów i nieraz nie kryli swego zadowolenia z choć chwilowego odwrócenia się ról, uznani zostali odpowiedzialnymi (jako społeczność) za wszystkie faktyczne i wyimaginowane nieszczęścia, które spadły na ludność Polską i za to mieli ponieść „zasłużoną karę”. W aneksie znalazły się sporządzone przez autora wykazy imienne przewodniczących Zarządów Tymczasowych, pełnomocników KC KP(b)B oraz LKZMB w regionie łomżyńskim w okresie od września do grudnia 1939 r., wykaz składu osobowego biur komitetów powiatowych $\mathrm{KP}(\mathrm{b}) \mathrm{B}$ regionu łomżyískiego działających od listopada do grudnia 1941 r., wykaz kandydatów do Zgromadzenia Ludowego Zachodniej Białorusi z regionu łomżyńskiego, wykazy obsady kadrowej radzieckich władz terenowych w regionie w latach 1939-1941, spisy naczelników rejonowych i miejskich oddziałów NKWD oraz rejonowych prokuratorów a także struktura i obsada personalna NKGB wg stanu z kwietnia 1941 r. Pracę kończą: indeks nazwisk i pseudonimów oraz indeks nazw geograficznych.

Gawrił Popow, O wojnie ojczyźnianej 1941-1945, Iskry, Warszawa 2005, ss. 144. Autor jest byłym merem Moskwy, uważanym za jednego z czołowych działaczy ruchu reformatorskiego. Jego praca wpisuje się w coraz bardziej obecny w rosyjskiej historiografii nurt prac, których autorzy rozprawiają się z mitem Wielkiej Wojny Ojczyźnianej. Nie oznacza to jednak, że bohaterstwo prostego żołnierza zostało przez Popowa zlekceważone. Przeciwnie, autor składa hołd żołnierzom walczącym z Hitlerem i oddaje cześć heroizmowi narodu rosyjskiego. Jego krytyka działań wojennych jest próbą pomocy narodowi rosyjskiemu w „oczyszczeniu” się z narzuconej przez 50 lat radzieckiej propagandy „wielkiego zwycięstwa”. Popow stara się pisać niewygodną do dziś prawdę wierząc, że pomoże to w naprawie współczesnej Rosji. Pisze operując statystyką, faktami zaczerpniętymi z "samizdatów", 
podpiera jąc się analizami przeprowadzonymi przez niezależnych analityków, publicystów i historyków. W rzetelny sposób stara się pokazać prawdziwe oblicze tej wojny, w tym prowadzoną przez wojska radzieckie masową grabież wszystkiego, co dało się zagrabić na „wyzwalanych” ziemiach Europy Środkowej.

Constantine Pleschakov, Szaleństwo Stalina. Pierwsze 10 dni wojny na froncie wschodnim, Wydawnictwo Magnum, Warszawa 2005, ss. 295. Jest to kolejna książka rosyjskiego historyka odkłamujące historię wojny niemiecko-radzieckiej. Autor opisuje w niej sytuację ZSRR w przededniu wojny oraz w czasie jej pierwszych dziesięciu dni, które zadecydowały o klęsce milionowych armii i nieomal o upadku ZSRR. Na podstawie najnowszych opracowań, odtajnionych dokumentów, nieocenzurowanych pamiętników i wspomnień uczestników tamtych wydarzeń oraz zbieranych wśród odchodzących z tego świata weteranów relacji kreśli w książce przejmujący obraz pierwszych dni wojny, kiedy Stalin, niezdolny do podejmowani decyzji i do końca nie potrafiący uwierzyć, że Hitler jednak zaatakował pierwszy, swoją niemocą paraliżował działania najwyższej kadry dowódczej. Zastanawia się, na ile realny był plan uderzenia prewencyjnego na Rzeszę, pokazuje, jak słaba i „ubezwłasnowolniona” była kadra oficerska, która ocalała z wielkiej czystki Armii Czerwonej w latach trzydziestych. W przejmujący sposób opisuje tragedię żołnierzy i dowódców z pierwszych linii frontu pozbawionych pomocy i oddanych na laskę wroga. Obala też mity o skuteczności reżimu stalinowskiego, o sprawności armii, o faktycznym (a nie propagandowym) przygotowaniu Kremla do wojny. Krytyce poddaje nie tylko zdolności mobilizacyjne i przemysłowe ZSRR. Udowadnia, że rzekomo wszechwładne i doskonale zorientowane NKWD i NKGB nie były w stanie zapobiec działaniu niemieckich oddziałów dywersyjnych, co kosztowało armie zgromadzone na zachodnich rubieżach radzieckiego imperium niemal całkowity paraliż łączności. Książka składa się z prologu, sześciu rozdziałów, epilogı, noty o wykorzystanych źródłach, obszernej bibliografii oraz indeksu nazwisk.

Richard Pipes, Rosja bolszewików, Wydawnictwo MAGNUM, Warszawa 2005, ss. 618. Jest to ostania część monumentalnej pracy poświęconej historii Rosji, uzupełniająca wydawane w Polsce sukcesywnie od 1990 r. Rosje carów i Rewolucję rosyjskq. Jak pisze we wstępie autor „Niniejsza książka była już właściwie gotowa, kiedy Związek Sowiecki się rozpadł, a nowe władze Rosji zdelegalizowały partię komunistyczną. Te niezwykłe wydarzenia stały się czymś w rodzaju kodu do Rosji bolszewików. Historykom nieczę- 
sto się zdarza, że przedmiot ich badań przechodzi do historii w chwili, gdy koíczą pracę nad dziejami jego genezy". Nie zmienia to faktu, że Rosja bolszeuików jest pracą wybitną, doskonale oddającą sytuację ludzi, którzy świadomi, że ich wysiłki opanowania świata nie przyniosą powodzenia zdecydowali się na budowanie ustroju komunistycznego $w$ jednym kraju. Praca składa się z dziewięciu rozdziałów. W rozdziale pierwszym i drugim autor opisuje wojnę domową - powstanie Armii Ochotniczej, krystalizowanie się Armii Czerwonej, walki z armiami Denikina, Wrangla i Kołczaka, obcą interwencję, kontrofensywę czerwonych, zwycięstwo bolszewików i jego koszty dla kraju i ludzi. W rozdziale trzecim charakteryzuje początki tworzenia się „czerwonego imperium”: zagarnięcie Ukrainy, podbój muzułmańskiego południa i ponowne opanowanie Kaukazu. Rozdział czwarty dotyczy nieudanej próby „eksportu” rewolucji na zachód Europy, o czym marzyli działacze komunistyczni z Leninem na czele. Pipes opisuje tu pierwsze próby wywołania rewolucji za granicą, powołanie Kominternu i przyczyny jego klęski, wojnę z Polską i klęskę idei niesienia rewolucji na bagnetach, powstawanie partii komunistycznych w Europie oraz początki stosowanej umiejętnie przez lata polityki manipulacji prasą zachodnią. $\mathrm{W}$ rozdziale piątym autor podjął się próby oceny i porównania komunizmu, faszyzmu i narodowego socjalizmu będących trzema największymi totalitaryzmami międzywojennej Europy, podkreślając na wstępie, że ,.działalność komunistów nie doprowadziła do wybuchu rewolucji światowej ale, paradoksalnie, dała początek ruchom, które przyswoiły sobie ducha komunizmu i naśladowały jego metody, aby z nim walczyć". Wrogość totalitaryzmów, zdaniem Pipesa, nie wynikała $z$ ich sprzecznych zasad i celów, ale raczej z walki o ten sam elektorat. Na potwierdzenie swej tezy pokazuje cechy wspólne trzech reżimów (manipulację tłumem, rolę ideologii), stara się jednak pokazać także cechy różniące te systemy. Rozdział szósty poświęcony jest roli i zadaniom nowej, bolszewickiej kultury, która stać się miała w założeniu jej twórców ważnym narzędziem propagandowym. Autor omawia w nim kolejno rolę cenzury komunistycznej, stosunek bolszewików do literatury, charakteryzuje teatr i kino jako doskonałe narzędzia propagandowe, pokazuje nowe zadania postawione przed malarstwem, architekturą i muzyką, opisuje także represje wobec intelektualistów nie chcących zaangażować się w tworzenie „proletkultury". Pisze także o zadaniach szkoły, problemie bezprizornych dzieci, walce $\mathrm{z}$ analfabetyzmem, a także o kształtowaniu nowego modelu rodziny. Uzupełnieniem tych przemyśleń jest rozdział siódmy poświęcony walce bolszewików $\mathrm{z}$ religią, tym opium dla mas, które uniemożliwiało bolszewikom podporządkowania sobie nie tylko woli, ale i duszy obywateli. Pipes opisuje 
stosunek komunistów do religii, zwalczanie Cerkwi prawosławnej, Kościoła katolickiego, Islamu i religii żydowskiej, zmasowaną akcję przeciwko wszelkim formom wiary oraz skutki, jakie te działania przyniosły społeczeństwu rosyjskiemu. Rozdział ósmy poświęcony jest NEP-owi, który Pipes określa mianem fałszywego termidora. Jak zauważa, kryzys wywołany komunizmem wojennym oraz dotychczasową politykę ekonomiczną doprowadził Rosję na skraj upadku. Świadomi tego bolszewicy starali się nie dopuścić do jakie kolwiek kontrrewolucji, która mogła ich zmieść, dlatego aby utrzymać się przy władzy gotowi byli zawrócić $\mathrm{z}$ wytyczonej już drogi, aby daí nadzieję społeczeństwu a jednocześnie wzmocnić się przed ostateczną z nim rozprawą. W rozdziale tym Pipes opisuje kolejno wielki bunt chłopski lat 1920-21, krwawo stłumione powstanie kronsztadzkie, zniesienie obowiązkowych kontyngentów i wprowadzenie NEP-u, nasilenie represji politycznych, procesy eserowców, klęskę głodu 1921 r., wzmożenie nadzoru nad zagranicznymi partiami komunistycznymi oraz początki współpracy niemiecko-radzieckiej. Ostatni rozdział poświęcony jest pierwszemu głębokiemu kryzysowi reżimu biurokratyzacji partii komunistycznej, słabnięciu pozycji Lenina i wzrostowi siły Stalina, walce Trackiego i Stalina o wpływy oraz zmianom, jakie przyniosła ze sobą śmierć wodza rewolucji. Całość pracy kończą uwagi autora o rewolucji rosyjskiej - jej przyczynach, zdobyciu władzy przez bolszewików, znaczeniu ideologii, różnicach pomiędzy leninizmem i stalinizmem, szacunkowemu bilansowi ofiar rewolucji oraz nieuchronności klęski komunizmu, słownik terminów rosyjskich, kalendarium wydarzen, obszerna bibliografia tematu oraz indeks nazwisk.

Boris Reitschuster, Wladimir Putin. Dokqd prowadzi Rosje, Świat Książki, Warszawa 2005, ss. 328. Książka ta opisuje drogę Władimira Putina na szczyty władzy. Autor w sposób niezwykle przekonujący kreśli obraz Rosji, w której przyszło Putinowi sięgnąć po władzę. Sugestywnie opisuje pierwsze lata urzędowania następcy Jelcyna, starając się odpowiedzieć na pytanie, na ile Putin prowadził swoją własną politykę, a na ile był, przynajmniej w pierwszych latach swych rządów, zakładnikiem dawnych koterii kremlowskich, których przez lata był aktywnym uczestnikiem. Stara się tė̇ odpowiedzieć na pytanie, czy rzeczywiście Putin jest silnym przywódcą wielkiego mocarstwa, czy też medialnym produktem speców od public relations oraz na ile jest on zależny od dawnych układów z KGB i czy oparcie się na ludziach $\mathrm{z}$ resortów siłowych to sposób na lepszą kontrolę nad tym co się dzieje w państwie, czy też zabezpieczenie się przed „nielojalnością" cywili, którą widział pracując w Moskwie i Sankt Petersburgu. Reitschuster szcze- 
gólowo opisuje też rolę kremlowskich oligarchów, którzy wynieśli Putina na Kreml, charakteryzuje działanie „systemu” utrzymującego Putina na szczytach popularności. Zastanawia się na ile popularność Putina jest dziełem służb, z których aktualny prezydent Rosji się wywodzi. Książka składa się z 9 rozdziałów, w których kolejno omówione są najważniejsze etapy kariery Putina od jego pracy w KGB oraz w merostwie w Sankt Petersburgu do obchodów dnia zwycięstwa nad faszyzmem w maju 1995 r. W oddzielnych rozdziałach omówiono też najważniejsze, bądź najbardziej charakterystyczne wydarzenia $\mathrm{z}$ okresu jego dotychczasowej kadencji: atak na teatr na Dubrowce, zatonięcie Kurska i wydarzenia w Biesłanie. Praca zaopatrzona jest w liczne zdjęcia, bibliografię tematu, kalendarium prezydenckie opracowane aż do maja 2005 roku oraz indeks osobowy.

Wojciech Śleszyński, Walka instytucji państwowych z bialoruskq dzialalnościq dywersyjnq 1920-1925, Polskie Towarzystwo Historyczne Oddział w Białymstoku, Białystok 2005, ss. 182. Książka ta jest drugą z cyklu publikacji źródłowych poświęconych historii ziem północno-wschodnich II RP. Dotyczy ona walki polskich instytucji paístwowych $\mathrm{z}$ białoruską działalnością dywersyjną w pierwszej połowie lat dwudziestych XX wieku, w okresie kształtowania się na tych ziemiach państwowości polskiej. Budzenia się świadomości narodowej Białorusinów oraz niespełnione aspiracje państwowe stały w sprzeczności z polskimi działaniami zmierzającymi do szybkiego wchłonięcia tych terenów jako części odrodzonej Rzeczypospolitej. W przygotowanym przez Wojciecha Śleszyńskiego zbiorze znalazły się dokumenty pochodzące $\mathrm{z}$ archiwów białoruskich (Państwowe Archiwum Obwodu Brzeskiego, Państwowe Archiwum Obwodu Grodzieńskiego), litewskich (Litewskie Centralne Archiwum Państwowe) oraz polskich (Centralne Archiwum Wojskowe, Archiwum Akt Nowych). Całość dokumentów przygotowana została do druku w porządku chronologic'znym i poprzedzona obszernym wstępem porządkującym i uzupełniającym naszą wiedzę na ten temat. $\mathrm{W}$ pracy zamieszczonych zostało 41 dokumentów wytworzonych przez terenowe organa władzy państwowej oraz policji. Dokumenty obejmują wydarzenia z lat 1922-1925. Sporą grupę stanowią rozkazy wojskowe dotyczące zwalczania aktywnej działalności dywersyjnej prowadzonej przez ludność białoruską. Bardzo ciekawy jest raport Oddziału II Sztabu Generalnego z marca 1923 informujący o zasięgu i skali działalności dywersyjnej na kresach północno-wschodnich oraz pismo wojewody nowogródzkiego do dowódcy Okręgu Korpusu w sprawie prawdopodobnego wybuchu powstania białoruskiego. O skali problemu świadczy też pismo z 7 maja 1925 r., w którym minister 
spraw wojskowych Władysław Sikorski udziela specjalnych pełnomocnictw gen. E. Rydzowi-Śmigłemu oraz gen. J. Romerowi na wypadek eskalacji działań grup dywersyjnych na ziemiach wschodnich II RP. Pewnym mankamentem tego zbioru jest brak indeksu osobowego, choć nie wpłynęło to na pogorszenie jej odbioru. Pozostaje mieć nadzieję na ukazanie się w najbliższych latach kolejnych dokumentów o tym, chyba najmniej do dziś poznanym fragmencie naszej wspólnej polsko-białoruskiej historii.

Paweł Wieczorkiewicz, Historia polityczna Polski 19.35-1945, „Książka i Wiedza", Warszawa 2005, ss. 563. Praca ta jest kolejną próbą oceny historii Polski lat drugiej wojny światowej $\mathrm{w}$ oparciu o najnowsze badania i studia źródłowe, jednak jak zaznacza we wstępie Paweł Wieczorkiewicz ,$[. .$.$] jest gorzka. Nie ma w niej happy endu i nie ma elementu zdrowego$ dydaktyzmu - triumfu dobra nad złem. Jest za to opis kolejnych błędów, niepowodzeí i porażek, które doprowadziły do tragicznego finału". Finałem tym, zdaniem Wieczorkiewicza, była nasza druzgocąca klęska, „na równi z Niemcami i Japonią", a na pewno większa niż tak, którą poniosły Włochy czy Rumunia. Jest to teza dość kontrowersyjna i moim zdaniem nie do końca przez autora obroniona, jednak skłaniająca do zastanowienia nad sposobami widzenia przez współczesną historię i politykę wydarzeń sprzed 60 lat. Zdaniem autora polska polityka począwszy od paktu Ribbentrop-Mołotow, poprzez układ Sikorski-Majski, a skończywszy na postanowieniach poczdamsko-jałtańskich była całkowicie ubezwłasnowolniona od woli naszych mniej lub bardziej szczerych sojuszników. Swoje wywody P. Wieczorkiewicz zaczyna od momentu śmierci J. Piłsudskiego, kiedy to skończyć się miała ważna w dziejach Polski epoka. Praca składa się z ośmiu rozdziałów, w których kolejno omówione zostały: ostatnie lata II RP, wrzesień 1939, sytuacja rządu polskiego na obczyźnie, okupacja niemiecka i radziecka, „sprawa polska" w kontaktach pomiędzy Londynem, Moskwą i Waszyngtonem, terror niemiecki i radziecki na ziemiach polskich, z uwzględnieniem roli polskich komunistów, „zmowa teherańska” oraz „agonia niepodległości”. W epilogu znalazły się rozważania autora o roli Polski lubelskiej. Całość pracy kończy obszerny indeks osobowy.

Operacja „Burza” i powstanie warszawskie 1944, red. Krzysztof Komorowski, Oficyna Wydawnicza RY'TM, Warszawa 2005, ss. 687. Książka ta stanowi podsumowanie dotychczasowych badań nad problemem operacji „Burza”. Autorami pracy są wybitni polscy historycy oraz uczestnicy tamtych wydarzeń. Po raz pierwszy dostajemy do ręki książkę, która w sposób 
kompleksowy omawia operacje wojskowe we wszystkich obszarach i okręgach, dzięki czemu możemy ocenić skalę i wartość polityczną tamtego zrywu. Praca dzieli się na trzy zasadnicze części. W części pierwszej znalazły się teksty trzech autorów dotyczące kolejno Polskiego Państwa Podziemnego (Stanisław Salomonowicz), Armii Krajowej (Krzysztof Komorowski) oraz ewaluacji koncepcji powstania powszechnego na ziemiach polskich w czasie okupacji (Marek Ney-Krwawicz). Część druga to kompleksowe opracowanie operac.ji „Burza” we wszystkich okręgach i obszarach II Rzeczypospolitej (Wołyń, Wilno, Nowogródek, Lwów, Białystok, Polesie, Lublin, Warszawa, Radom-Kielce, Kraków, Śląsk i Łódź, Pomorze i Wielkopolska). Uzupełnieniem tej części jest tekst autorstwa Tomasza Strzembosza o małych ojczyznach - terenach wyzwolonych przez AK w latach 1943-1944. W ostatniej części pracy omówione zostało Powstanie Warszawskie. Niezwykle cenne są dołączone do tej części refleksje po latach Jana Nowaka-Jeziorańskiego oraz opracowanie Jerzego Kłoczowskiego o Powstaniu Warszawskim w pamięci i historiografii. Pracę kończy Epilog Armii Krajowej autorstwa Andrzeja Chmielarza oraz Testament Polski Walczącej, a także indeks nazwisk i pseudonimów oraz indeks miejscowości

Tadeusz Wolsza, Za żelaznq kurtynq. Europa Środkowo-Wschodnia, Zwiqzek Sowiecki i Józef Stalin $w$ opiniach polskiej emigracji politycznej $w$ Wielkiej Brytanii 1944/1945-1953, Instytut Historii PAN, Warszawa 2005, ss. 288. Niniejsza praca składa się z siedmiu rozdziałów. W rozdziale pierwszym omówione zostały emigracyjna polityka informacyjna na temat Europy Środkowo-Wschodniej i Związku Radzieckiego od 1945 r. do połowy lat pięćdziesiątych: główne kierunki polityki informacy jnej władz RP na obczyźnie, polskie instytucje i komisje zajmujące się tymi zagadnieniami, działalność edytorsko-wydawnicza (książki, druki ulotne, instrukcje, broszury, biuletyny). W rozdziale tym autor charakteryzuje także polskie czasopisma emigracyjne zajınujące się w szerszym zakresie tematyką środkowoeuropejską oraz sowiecką. Rozdział drugi, trzeci i czwarty opisują sytuację polityczną w Związku Radzieckim widzianą oczyma emigracji. W rozdziale drugim omówione zostały aspiracje mocarstwowe Kremla widziane przez emigrację jako jedno z głównych zagrożeń dla stabilności i pokoju w tej części Europy, od wdrażania przez Kreml ładu jałtańskiego, przez główne kierunki rozwoju radzieckiej polityki zagranicznej, aż do uznawanej za całkiem realną III wojny światowej, której preludium miały być wydarzenia na Półwyspie Koreańskim. $\mathrm{W}$ rozdziale trzecim $\mathrm{T}$. Wolsza opisuje jak środowiska emigracyjne oceniały i opisywały wewnętrzną sytuację w Związku Radzieckim w latach 
1945-1953. Swoje rozważania podzielił na kilka zagadnień: ustrój, sprawy gospodarcze, życie codzienne, polityka wobec Cerkwi, łagry i polityka represyjna. W rozdziale czwartym, moim zdaniem najciekawszym w całej pracy, znajdziemy informacje o odbiorze przez polską emigrację specyfiki życia politycznego w ZSRR, na co składały się próby opracowania i napisania niezakłamanej biografii Stalina oraz oceny ówczesnych elit władzy. Rozdział piąty poświęcony jest stanowisku „polskiego Londynu” wobec wydarzeń w Europie Środkowo-Wschodniej w latach 1944-1948, a więc w czasie utrwalania na tym terenie wpływów wiernych Kremlowi partii komunistycznych. Kolejno omówione zostały: instalowania się komunistów, stopniowa sowietyzacja podporządkowanych Kremlowi państw, poglądy emigracji na Plan Marshalla oraz wydarzenia w Czechosłowacji w $1948 \mathrm{r}$. W rozdziale szóstym znalazły się emigracyjne opinie o polityce Związku Radzieckiego oraz partii komunistycznych w państwach satelickich wobec Kościołów i hierarchii kościelnej. W rozdziale siódmym $\mathrm{T}$. Wolsza zamieścił obszerny wybór emigracyjnych rysunków satyrycznych, fraszek i karykatur, których wspólnym bohaterem jest Józef Stalin. Praca zawiera obszerną bibliografię tematu oraz indeks osobowy.

Studia z Dziejów Rosji i Europy Środkowo-Wschodniej (I-XL). Przewodnik bibliograficzny, oprac. Daniel Boćkowski, Wydawnictwo Neriton, Warszawa 2005, ss. 63. Jest to nieoceniona pomoc dla wszystkich, którzy zajmują się historią ZSRR, Rosji i Europy Wschodniej. Przewodnik ma układ przedmiotowo-chronologiczny. Teksty w poszczególnych działach, których jest 8 (Polska w Europie Środkowej, Europa Wschodnia, Rosja i ZSRR, Zakaukazie, kraje bałtyckie i Skandynawia, Europa Środkowa i Bałkany, Wschód i Zachód Europy, Varia), umieszczone są dodatkowo w podziale na kraje, których dotyczą. Ponieważ jeden tekst często dotyczy problematyki szerszej, np. stosunków dwu lub wielostronnych, tytuł artykułu może się znaleźć nawet $\mathrm{w}$ kilku miejscach. Ma to ułatwić przeszukiwanie zawartości Studiów pod kątem preferowanej problematyki badawczej. W poszczególnych działach artykuły ułożone są w porządku chronologicznym od wydarzeń z początku XIX wieku do czasów współczesnych. Gwiazdkami oddzielone zostały materiały zamieszczane $\mathrm{w}$ dziale recenzyjnym (przeglądy historiograficzne i artykuły recenzyjne). Przewodnik nie zawiera natomiast informacji o umieszczanych w Studiach recenzjach, notkach recenzyjnych i polemikach, informacjach jubileuszowych, sprawozdaniach z konferencji i sympozjów, życiu naukowym; nie zawiera też not pośmiertnych (ad memoriam). 